\title{
Histological changes in the vulva and vagina from ovariectomised rats undergoing oestrogen treatment
}

\author{
R.F. Mocan-Hognogi ${ }^{1}$, N. Costin ${ }^{1}$, A. Malutan ${ }^{1}$, R. Ciortea ${ }^{1}$, I.A. Trif ${ }^{1}$, A.L. Nagy ${ }^{2}$, \\ M.L. Bogdan ${ }^{3}$, D. Mihu ${ }^{1}$ \\ ${ }^{1} 2^{\text {nd }}$ Clinic of Obstetrics and Gynaecology, "Iuliu Hatieganu" University of Medicine and Pharmacy, Cluj-Napoca, Romania \\ ${ }^{2}$ Department of Veterinary Toxicology, University of Agricultural Sciences and Veterinary Medicine, Cluj-Napoca, Romania \\ ${ }^{3}$ Department of Obstetrics, University of Agricultural Sciences and Veterinary Medicine, Cluj-Napoca, Romania
}

[Received: 26 January 2016; Accepted: 31 March 2016]

Background: The purpose of this study was to assess the histological changes occurring in the vagina and vulva in ovariectomised female rats, as well as the response to the administration of injectable oestrogens.

Material and methods: We used 30 female Wistar white rats, distributed as follows: group 1 - the control group, group 2 - the operated but untreated rats, and groups 3, 4 and 5-operated rats, to which oestrogenic treatment was administered (Estradiol, Estradurin, Sintofolin) at a dosage of $0.2 \mathrm{mg} / \mathrm{rat} /$ day. After 14 days of treatment, all animals were sacrificed and vaginal and vulvar biopsies were taken from all groups.

Results: In group 2, we encountered structural changes of the vaginal mucosa, with severe atrophy and alterations in the thickness of the vagina and vulva. In groups 3, 4 and 5 we found marked hyperplasia of the vaginal and vulvar epithelium, eosinophilic and mast cell infiltration in the chorion.

Conclusions: Our study proves that the histopathological changes during anoestrus after administration of oestrogens are cell hyperplasia, thickening of the superficial mucosal layer, eosinophilic and mast cells infiltrations, and chorionic congestion. Furthermore, we demonstrated that Estradiol therapy induces the most evident histological changes when compared to synthetic oestrogens such as Estradurin or Sintofolin. (Folia Morphol 2016; 74, 4: 467-473)

Key words: anoestrus, hormone replacement therapy, vulvo-vaginal atrophy, oestrogen receptors

\section{INTRODUCTION}

General and local modifications appear during menopause as a response to the deficiency in oestrogens, which may occur progressively in natural menopause, or suddenly in surgical menopause [11, 24]. Such morphological and structural modifications are often associated with alterations in various organs, thus influencing the quality of life $[10,23]$.

Over the last years, there has been some controversy over hormone replacement therapy, due to its various side effects, such as breast, endometrial and ovarian cancer, cerebrovascular accident, or thromboembolic 
disease $[7,20,25]$. These risks can be avoided through correct monitoring, mammography and echography with measurement of endometrial thickness [3].

A decrease in hormonal activity can be experimentally created through bilateral ovariectomy in female rats [17]. The ovariectomy in the rat induces permanent anoestrus, but it is not similar to the human physiological menopause. This experimental model plays an important role in understanding the pathophysiological modifications of the anoestrus syndrome, thus helping in the development of multiple adjuvant therapies $[5,12]$.

It is known that the action of oestrogens is exerted through receptors in the genital tract, the mammary gland and the nervous system [26].

Oestrogens have an important regulating effect on cell proliferation, a function that is mediated by the alpha (ER- $\alpha$ ) and beta (ER- $\beta$ ) oestrogenic receptors [9]. Under normal conditions, ER- $\alpha$ receptors are expressed in the adenohypophysis, breast, uterus, uterine tract and vagina, while ER- $\beta$ receptors are expressed in the urinary tract, ovary, thyroid, skin, lung and thymus [18, 33]. Due to the large number of oestrogenic receptors in the vagina and vulva, the latter will react promptly to the action of oestrogens, both natural and synthetic $[1,2,8]$.

This experimental study aims to assess the histological modifications occurring in the vagina and vulva of ovariectomised female rats, as well as the response to the administration of injectable oestrogens.

\section{MATERIALS AND METHODS}

This study was conducted using a total of 30 female Wistar white rats, with an average weight of $200 \mathrm{~g}$, obtained from the laboratory animal facility of the "Iuliu Hatieganu" University of Medicine and Pharmacy of Cluj-Napoca. Throughout the experiment, the rats were given standard food and water ad libitum, thus observing the standard conditions required by the current legislation on the protection of laboratory animals.

The following study groups were created:

- Group 1 - control group (no surgical intervention, no oestrogenic treatment, pre anoestrus), including 5 subjects;

- Group 2 - operated, anoestrus, without treatment -5 subjects;

- Group 3 - operated and treated with Estradiol (i.e. a natural oestrogen, at a dosage of $0.2 \mathrm{mg} / \mathrm{day} / \mathrm{rat}$, for a period of 14 days) -6 subjects;

- Group 4 - operated and treated with Estradurin (i.e. a synthetic oestrogen, at a dosage of $0.2 \mathrm{mg} /$ /rat, every 7 days, for a period of 14 days) 7 subjects;

- Group 5 - operated and treated with Sintofolin (i.e. a synthetic oestrogen, at a dosage of $0.2 \mathrm{mg} /$ /day/rat, for a period of 14 days) -7 subjects.

Bilateral ovariectomy was performed in 25 of the 30 female rats included in the study. The ovariectomy was performed in accordance with the technique described by Nevalainen et al. [22]. The animals were anesthetized by intramuscular injection of a mixture of Xylasine (10 mg/kg, Xylocontact) and ketamine $(100 \mathrm{mg} / \mathrm{kg})$. The neuroleptanalgesia was induced for a period of 30-90 $\mathrm{min}$, time needed for the surgical intervention. Under sterile conditions, a $2-3 \mathrm{~cm}$ ventral midline incision was made into the skin and muscle wall of the upper abdomen (to expose the ovaries). After permanent haemostasis, the ovaries were removed and the skin was closed with interrupted 3-0 silk sutures. The anoestrus phase was considered to be installed 15 days after surgery. To confirm this, the oestradiol level was tested 15 days after surgery, in order to compare oestradiol hormonal levels pre and post-surgery.

Once the anoestrus was confirmed in all study groups, we began administering various injectable oestrogen hormonal formulas, over a 14-day period.

Estradiol (Biofarm, Bucharest, Romania, Zip code: 031212) was used for group 3; each $1 \mathrm{~mL}$-vial of injectable oily liquid contained $2.5 \mathrm{mg}$ oestradiol, which was diluted in $9 \mathrm{~mL}$ neutralised and sterilised sunflower oil, so that for a dose $0.2 \mathrm{mg}$ of oestradiol/ $/ \mathrm{rat} /$ day, we administered $0.8 \mathrm{~mL}$ of oily solution. Estradurin (Pharmacia \& Upjohn Company LLC [a subsidiary of Pfizer Inc.]), 7000 Portage Road Kalamazoo, MI 49001 United States, is a synthetic oestrogen which was used for group 4; each $2 \mathrm{~mL}$-vial contained $80 \mathrm{mg}$ of powdered polyoestradiol phosphate, diluted in $38 \mathrm{~mL}$ of distilled water, so that for $0.2 \mathrm{mg}$ of oestradiol/ $/ \mathrm{rat} /$ day, we administered $0.1 \mathrm{~mL}$ solution. Estradurin was administered at 7-day intervals since it is a powerful phosphatase inhibitor, with a particularly slow release, ensuring considerable oestrogenic activity for a prolonged period of time, even weeks after the injection. Sintofolin (Terapia S.A, 400632, ClujNapoca, jud. Cluj, Romania), a synthetic oestrogen, was used for group 5; each $2 \mathrm{~mL}$ vial of injectable oily liquid contained $5 \mathrm{mg}$ of hexoestrol diacetate, which was diluted with $8 \mathrm{~mL}$ of neutralised and sterilised sunflower oil, so that $0.4 \mathrm{~mL}$ of oily solution was administered for $0.2 \mathrm{mg} / \mathrm{rat} /$ day. 
Table 1. Weight of the rats/day

\begin{tabular}{|c|c|c|c|c|c|c|c|c|c|c|c|c|c|c|}
\hline \multirow{2}{*}{$\begin{array}{l}\text { Group (Gr); } \\
\text { subject (S) }\end{array}$} & \multicolumn{14}{|c|}{ Body weight } \\
\hline & $\begin{array}{c}\text { Day } \\
1\end{array}$ & $\begin{array}{c}\text { Day } \\
2\end{array}$ & $\begin{array}{c}\text { Day } \\
\mathbf{3}\end{array}$ & $\begin{array}{c}\text { Day } \\
4\end{array}$ & $\begin{array}{c}\text { Day } \\
\mathbf{5}\end{array}$ & $\begin{array}{c}\text { Day } \\
6\end{array}$ & $\begin{array}{c}\text { Day } \\
7\end{array}$ & $\begin{array}{c}\text { Day } \\
\mathbf{8}\end{array}$ & $\begin{array}{c}\text { Day } \\
\mathbf{9}\end{array}$ & $\begin{array}{c}\text { Day } \\
10\end{array}$ & $\begin{array}{c}\text { Day } \\
11\end{array}$ & $\begin{array}{c}\text { Day } \\
12\end{array}$ & $\begin{array}{c}\text { Day } \\
\mathbf{1 3}\end{array}$ & $\begin{array}{c}\text { Day } \\
14\end{array}$ \\
\hline Gr 2; S6 & $235 \mathrm{~g}$ & $230 \mathrm{~g}$ & $233 \mathrm{~g}$ & $235 \mathrm{~g}$ & $238 \mathrm{~g}$ & $243 \mathrm{~g}$ & $240 \mathrm{~g}$ & $240 \mathrm{~g}$ & $240 \mathrm{~g}$ & $239 \mathrm{~g}$ & $239 \mathrm{~g}$ & $238 \mathrm{~g}$ & $242 \mathrm{~g}$ & $242 \mathrm{~g}$ \\
\hline Gr 2; S7 & $225 \mathrm{~g}$ & $225 \mathrm{~g}$ & $221 \mathrm{~g}$ & $223 \mathrm{~g}$ & $220 \mathrm{~g}$ & $242 \mathrm{~g}$ & $238 \mathrm{~g}$ & $240 \mathrm{~g}$ & $241 \mathrm{~g}$ & $239 \mathrm{~g}$ & $240 \mathrm{~g}$ & $241 \mathrm{~g}$ & $242 \mathrm{~g}$ & $238 \mathrm{~g}$ \\
\hline Gr 2; S8 & $210 \mathrm{~g}$ & $215 \mathrm{~g}$ & $237 \mathrm{~g}$ & $230 \mathrm{~g}$ & $237 \mathrm{~g}$ & $232 \mathrm{~g}$ & $222 \mathrm{~g}$ & $225 \mathrm{~g}$ & $226 \mathrm{~g}$ & $225 \mathrm{~g}$ & $224 \mathrm{~g}$ & $222 \mathrm{~g}$ & $225 \mathrm{~g}$ & $225 \mathrm{~g}$ \\
\hline $\mathrm{Gr} 2 ; \mathrm{S} 9$ & $250 \mathrm{~g}$ & $250 \mathrm{~g}$ & $256 \mathrm{~g}$ & $254 \mathrm{~g}$ & $256 \mathrm{~g}$ & $263 \mathrm{~g}$ & $260 \mathrm{~g}$ & $255 \mathrm{~g}$ & $255 \mathrm{~g}$ & $258 \mathrm{~g}$ & $256 \mathrm{~g}$ & $257 \mathrm{~g}$ & $256 \mathrm{~g}$ & $259 \mathrm{~g}$ \\
\hline Gr 2; S10 & $225 \mathrm{~g}$ & $225 \mathrm{~g}$ & $224 \mathrm{~g}$ & $222 \mathrm{~g}$ & $228 \mathrm{~g}$ & $229 \mathrm{~g}$ & $227 \mathrm{~g}$ & $225 \mathrm{~g}$ & $226 \mathrm{~g}$ & $225 \mathrm{~g}$ & $225 \mathrm{~g}$ & $226 \mathrm{~g}$ & $227 \mathrm{~g}$ & $226 \mathrm{~g}$ \\
\hline Gr 3; S11 & $233 \mathrm{~g}$ & $230 \mathrm{~g}$ & $193 \mathrm{~g}$ & $200 \mathrm{~g}$ & $194 \mathrm{~g}$ & $196 \mathrm{~g}$ & $194 \mathrm{~g}$ & $220 \mathrm{~g}$ & $218 \mathrm{~g}$ & $222 \mathrm{~g}$ & $220 \mathrm{~g}$ & $220 \mathrm{~g}$ & $222 \mathrm{~g}$ & $221 \mathrm{~g}$ \\
\hline Gr 3; S12 & $206 \mathrm{~g}$ & $210 \mathrm{~g}$ & $211 \mathrm{~g}$ & $208 \mathrm{~g}$ & $206 \mathrm{~g}$ & $205 \mathrm{~g}$ & $208 \mathrm{~g}$ & $210 \mathrm{~g}$ & $212 \mathrm{~g}$ & $215 \mathrm{~g}$ & $210 \mathrm{~g}$ & $212 \mathrm{~g}$ & $210 \mathrm{~g}$ & $210 \mathrm{~g}$ \\
\hline Gr 3; S13 & $250 \mathrm{~g}$ & $250 \mathrm{~g}$ & $247 \mathrm{~g}$ & $245 \mathrm{~g}$ & $242 \mathrm{~g}$ & $246 \mathrm{~g}$ & $244 \mathrm{~g}$ & $248 \mathrm{~g}$ & $243 \mathrm{~g}$ & $240 \mathrm{~g}$ & $245 \mathrm{~g}$ & $242 \mathrm{~g}$ & $240 \mathrm{~g}$ & $242 \mathrm{~g}$ \\
\hline Gr 3; S14 & $215 \mathrm{~g}$ & $215 \mathrm{~g}$ & $215 \mathrm{~g}$ & $211 \mathrm{~g}$ & $210 \mathrm{~g}$ & $218 \mathrm{~g}$ & $218 \mathrm{~g}$ & $215 \mathrm{~g}$ & $218 \mathrm{~g}$ & $218 \mathrm{~g}$ & $215 \mathrm{~g}$ & $215 \mathrm{~g}$ & $215 \mathrm{~g}$ & $219 \mathrm{~g}$ \\
\hline Gr 3; S15 & $260 \mathrm{~g}$ & $225 \mathrm{~g}$ & $211 \mathrm{~g}$ & $210 \mathrm{~g}$ & $216 \mathrm{~g}$ & $213 \mathrm{~g}$ & $213 \mathrm{~g}$ & $215 \mathrm{~g}$ & $215 \mathrm{~g}$ & $213 \mathrm{~g}$ & $217 \mathrm{~g}$ & $218 \mathrm{~g}$ & $215 \mathrm{~g}$ & $212 \mathrm{~g}$ \\
\hline Gr 3; S16 & $225 \mathrm{~g}$ & $230 \mathrm{~g}$ & $236 \mathrm{~g}$ & $233 \mathrm{~g}$ & $230 \mathrm{~g}$ & $228 \mathrm{~g}$ & $223 \mathrm{~g}$ & $223 \mathrm{~g}$ & $220 \mathrm{~g}$ & $225 \mathrm{~g}$ & $225 \mathrm{~g}$ & $222 \mathrm{~g}$ & $225 \mathrm{~g}$ & $228 \mathrm{~g}$ \\
\hline Gr 4; S17 & $230 \mathrm{~g}$ & $210 \mathrm{~g}$ & $195 \mathrm{~g}$ & $195 \mathrm{~g}$ & $194 \mathrm{~g}$ & $196 \mathrm{~g}$ & $192 \mathrm{~g}$ & $195 \mathrm{~g}$ & $195 \mathrm{~g}$ & $198 \mathrm{~g}$ & $196 \mathrm{~g}$ & $197 \mathrm{~g}$ & $195 \mathrm{~g}$ & $196 \mathrm{~g}$ \\
\hline Gr 4; S18 & $225 \mathrm{~g}$ & $200 \mathrm{~g}$ & $207 \mathrm{~g}$ & $208 \mathrm{~g}$ & $210 \mathrm{~g}$ & $206 \mathrm{~g}$ & $205 \mathrm{~g}$ & $205 \mathrm{~g}$ & $208 \mathrm{~g}$ & $207 \mathrm{~g}$ & $207 \mathrm{~g}$ & $208 \mathrm{~g}$ & $205 \mathrm{~g}$ & $208 \mathrm{~g}$ \\
\hline Gr 4; S19 & $230 \mathrm{~g}$ & $225 \mathrm{~g}$ & $240 \mathrm{~g}$ & $225 \mathrm{~g}$ & $216 \mathrm{~g}$ & $218 \mathrm{~g}$ & $213 \mathrm{~g}$ & $215 \mathrm{~g}$ & $216 \mathrm{~g}$ & $215 \mathrm{~g}$ & $217 \mathrm{~g}$ & $215 \mathrm{~g}$ & $214 \mathrm{~g}$ & $216 \mathrm{~g}$ \\
\hline Gr 4; S2O & $230 \mathrm{~g}$ & $215 \mathrm{~g}$ & $198 \mathrm{~g}$ & $210 \mathrm{~g}$ & $217 \mathrm{~g}$ & $214 \mathrm{~g}$ & $212 \mathrm{~g}$ & $215 \mathrm{~g}$ & $215 \mathrm{~g}$ & $218 \mathrm{~g}$ & $217 \mathrm{~g}$ & $215 \mathrm{~g}$ & $218 \mathrm{~g}$ & $216 \mathrm{~g}$ \\
\hline Gr 4; S21 & $200 \mathrm{~g}$ & $205 \mathrm{~g}$ & $226 \mathrm{~g}$ & $225 \mathrm{~g}$ & $227 \mathrm{~g}$ & $226 \mathrm{~g}$ & $226 \mathrm{~g}$ & $226 \mathrm{~g}$ & $225 \mathrm{~g}$ & $226 \mathrm{~g}$ & $225 \mathrm{~g}$ & $227 \mathrm{~g}$ & $226 \mathrm{~g}$ & $225 \mathrm{~g}$ \\
\hline Gr 4; S22 & $220 \mathrm{~g}$ & $221 \mathrm{~g}$ & $226 \mathrm{~g}$ & $227 \mathrm{~g}$ & $228 \mathrm{~g}$ & $224 \mathrm{~g}$ & $221 \mathrm{~g}$ & $225 \mathrm{~g}$ & $224 \mathrm{~g}$ & $229 \mathrm{~g}$ & $225 \mathrm{~g}$ & $225 \mathrm{~g}$ & $224 \mathrm{~g}$ & $223 \mathrm{~g}$ \\
\hline Gr 4; S23 & $220 \mathrm{~g}$ & $225 \mathrm{~g}$ & $240 \mathrm{~g}$ & $238 \mathrm{~g}$ & $236 \mathrm{~g}$ & $234 \mathrm{~g}$ & $220 \mathrm{~g}$ & $227 \mathrm{~g}$ & $228 \mathrm{~g}$ & $230 \mathrm{~g}$ & $228 \mathrm{~g}$ & $227 \mathrm{~g}$ & $228 \mathrm{~g}$ & $229 \mathrm{~g}$ \\
\hline Gr 5; S24 & $210 \mathrm{~g}$ & $205 \mathrm{~g}$ & $215 \mathrm{~g}$ & $213 \mathrm{~g}$ & $212 \mathrm{~g}$ & $220 \mathrm{~g}$ & $209 \mathrm{~g}$ & $210 \mathrm{~g}$ & $211 \mathrm{~g}$ & $212 \mathrm{~g}$ & $210 \mathrm{~g}$ & $212 \mathrm{~g}$ & $213 \mathrm{~g}$ & $212 \mathrm{~g}$ \\
\hline Gr 5; S25 & $200 \mathrm{~g}$ & $200 \mathrm{~g}$ & $187 \mathrm{~g}$ & $186 \mathrm{~g}$ & $186 \mathrm{~g}$ & $186 \mathrm{~g}$ & $183 \mathrm{~g}$ & $185 \mathrm{~g}$ & $186 \mathrm{~g}$ & $187 \mathrm{~g}$ & $185 \mathrm{~g}$ & $183 \mathrm{~g}$ & $186 \mathrm{~g}$ & $185 \mathrm{~g}$ \\
\hline Gr 5; S26 & $225 \mathrm{~g}$ & $240 \mathrm{~g}$ & $241 \mathrm{~g}$ & $240 \mathrm{~g}$ & $244 \mathrm{~g}$ & $242 \mathrm{~g}$ & $245 \mathrm{~g}$ & $243 \mathrm{~g}$ & $242 \mathrm{~g}$ & $244 \mathrm{~g}$ & $245 \mathrm{~g}$ & $245 \mathrm{~g}$ & $243 \mathrm{~g}$ & $244 \mathrm{~g}$ \\
\hline Gr 5; S27 & $240 \mathrm{~g}$ & $230 \mathrm{~g}$ & $212 \mathrm{~g}$ & $210 \mathrm{~g}$ & $212 \mathrm{~g}$ & $214 \mathrm{~g}$ & $209 \mathrm{~g}$ & $210 \mathrm{~g}$ & $211 \mathrm{~g}$ & $210 \mathrm{~g}$ & $212 \mathrm{~g}$ & $211 \mathrm{~g}$ & $212 \mathrm{~g}$ & $212 \mathrm{~g}$ \\
\hline Gr 5; S28 & $262 \mathrm{~g}$ & $220 \mathrm{~g}$ & $215 \mathrm{~g}$ & $210 \mathrm{~g}$ & $212 \mathrm{~g}$ & $211 \mathrm{~g}$ & $211 \mathrm{~g}$ & $212 \mathrm{~g}$ & $211 \mathrm{~g}$ & $213 \mathrm{~g}$ & $215 \mathrm{~g}$ & $212 \mathrm{~g}$ & $211 \mathrm{~g}$ & $214 \mathrm{~g}$ \\
\hline Gr 5; S29 & $260 \mathrm{~g}$ & $210 \mathrm{~g}$ & $214 \mathrm{~g}$ & $212 \mathrm{~g}$ & $213 \mathrm{~g}$ & $214 \mathrm{~g}$ & $209 \mathrm{~g}$ & $210 \mathrm{~g}$ & $215 \mathrm{~g}$ & $212 \mathrm{~g}$ & $210 \mathrm{~g}$ & $214 \mathrm{~g}$ & $210 \mathrm{~g}$ & $212 \mathrm{~g}$ \\
\hline Gr 5; S30 & $200 \mathrm{~g}$ & $200 \mathrm{~g}$ & $213 \mathrm{~g}$ & $205 \mathrm{~g}$ & $202 \mathrm{~g}$ & $204 \mathrm{~g}$ & $201 \mathrm{~g}$ & $200 \mathrm{~g}$ & $200 \mathrm{~g}$ & $202 \mathrm{~g}$ & $203 \mathrm{~g}$ & $204 \mathrm{~g}$ & $203 \mathrm{~g}$ & $202 \mathrm{~g}$ \\
\hline
\end{tabular}

At the end of the study, 14 days after treatment, all the animals were sacrificed using the cervical dislocation method. Vaginal and vulvar biopsies were taken from all groups, and the samples were subjected to a histopathological examination, so as to obtain the necessary results and data for attaining the objective of this experimental study.

Vaginal and vulvar biopsies were taken from all groups and the samples were examined by a pathologist from the Department of Veterinary Toxicology of the University of Agricultural Sciences and Veterinary Medicine, Cluj-Napoca.

The protocol used in this experimental study was approved by the Ethics Committee of the "Iuliu Hatieganu" University of Medicine and Pharmacy of ClujNapoca (approval no. 116/06.03.2015).
For the histopathological examination, biopsies from the vaginal mucosa and vulva were placed in $10 \%$ neutral buffered formalin, included in paraffin, and 4 micrometre sections were cut with a Leica RM 2125 RT microtome. The sections were stained with the haematoxylin-eosin (HE) method. They were examined with an Olympus BX 51 microscope; the images were taken with an Olympus DP 25 digital camera, and then edited with the help of the Olympus Cell B application.

\section{Statistical analysis}

We first performed a descriptive analysis of the variables, at both the parametric (using means and standard deviations) and the graphic levels. Since all variables are quantitative (scales), we assessed the 
normality of their distribution, in order to establish the type of tests to be applied (parametric or nonparametric). The final decision was taken on the basis of the Shapiro-Wilk test.

The variation in corporal mass was studied on the sample of 25 operated rats. Since we measured the same individuals repeatedly, we performed the Repeated Measures type of multivariate analysis of variance (MANOVA).

We compared the pre- and post-surgery Estradiol values using the Paired Samples Student $(t)$ test.

The comparison of the thickness of the vagina and vulva, among the five study groups, was performed using the ANOVA method (analysis of variance in a simple format). The standard level of significance considered was $5 \%$, but when the results were significant at $1 \%$ level, this was clearly stated.

\section{RESULTS}

During the study, we recorded variations of the body mass of each subject, leading to statistically significant differences among the groups, such as an increase in weight in group 2 rats and a decrease in weight in groups 3, 4 and 5 (Table 1, Fig. 1).

Surgically-induced anoestrus was demonstrated by determining post-surgery oestradiol levels, which were significantly different between the study groups $(p=0.000<0.01)$ (Fig. 2).

There were statistically significant differences in thickness of the vaginal epithelium between the groups treated with injectable oestrogens, $(p=0.000<0.05)$, proving that the type of treatment has a significant influence on the thickness of the vagina (Fig. 3).

There were statistically significant differences in thickness of the vulva between the groups treated with injectable oestrogens $(p=0.000<0.05)$. We therefore

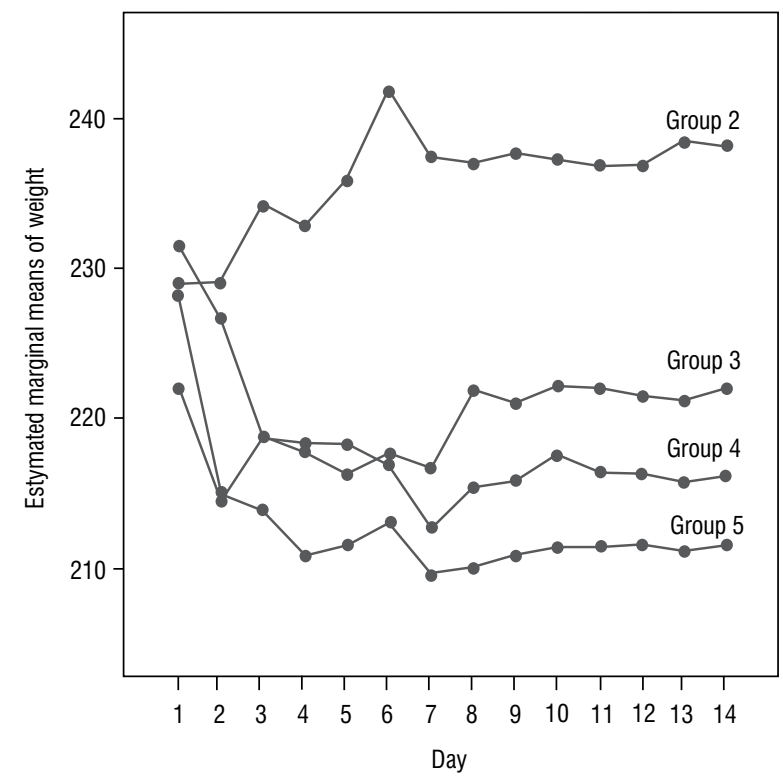

Figure 1. Variation of weight depending on treatment.

concluded that the type of treatment has a significant influence on the thickness of the vulva (Fig. 4).

Atrophy of the vulva and vagina was calculated using 3-point morphometric measurements; this method insured a real morphological quantification and found statistically significant differences between groups.

Furthermore, during the study, we assessed the structural changes of the vagina and vulva on the biopsy samples. Apart from the changes in the diameter of uterine horns found in the oestrogenic treatment groups, no macroscopic lesions were clearly noticeable during necropsy. The sections in the vaginal epithelium in group 1 (the control group) exhibited a normal morphology. The subjects in group 2 had a mild congestion of the submucosa,

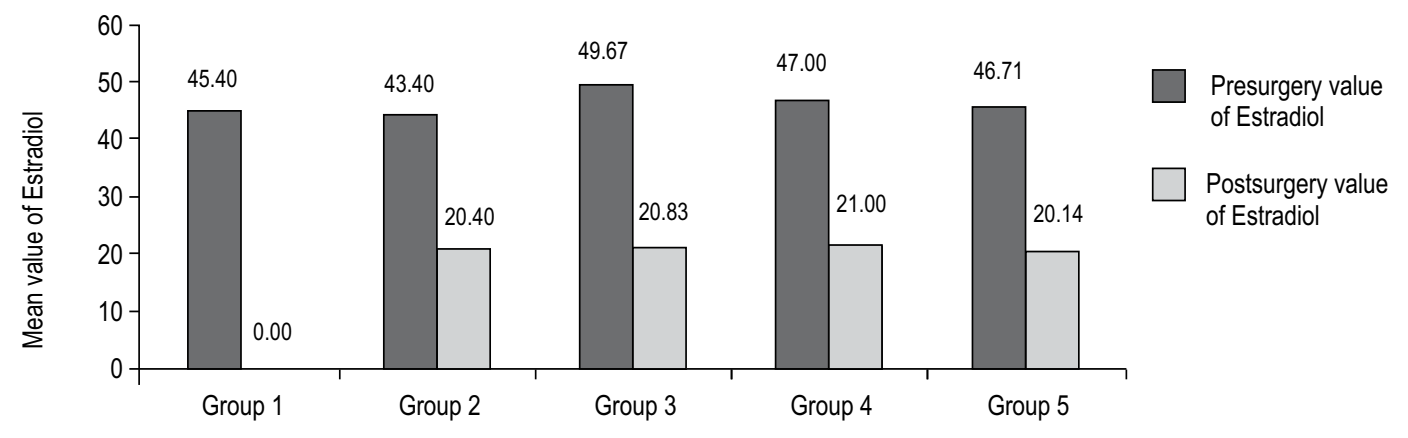

Figure 2. Comparison of pre/post-surgery oestradiol values. 


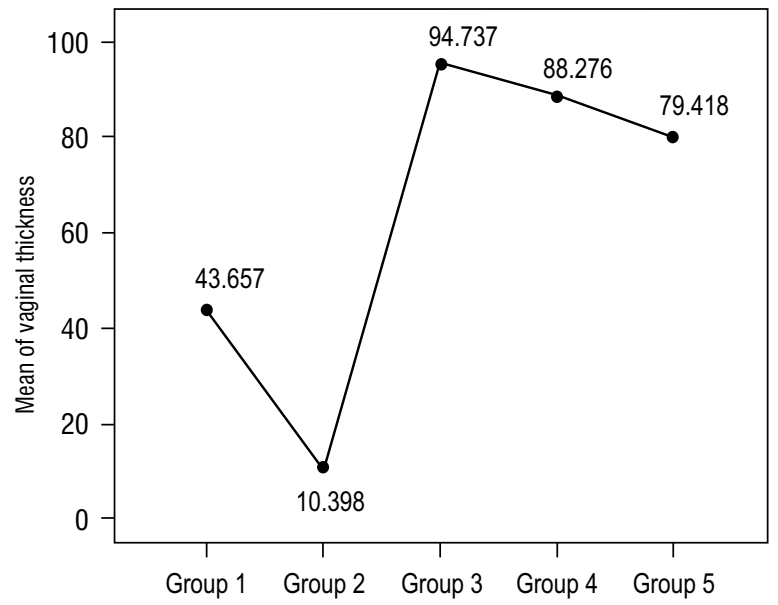

Figure 3. Differences in thickness of vaginal epithelium.

with eosinophils and mast cells in the chorion and submucosa and marked atrophy in the epithelium. Subjects in groups 3, 4 and 5, treated with various oestrogenic substances, exhibited marked vaginal hyperplasia, with an abundance of eosinophils and sporadic mast cells in the chorion. With regard to the vulva, group 1 was found to have a normal histological structure, while group 2 exhibited severe atrophy of the mucosa. The subjects in groups 3, 4 and 5,

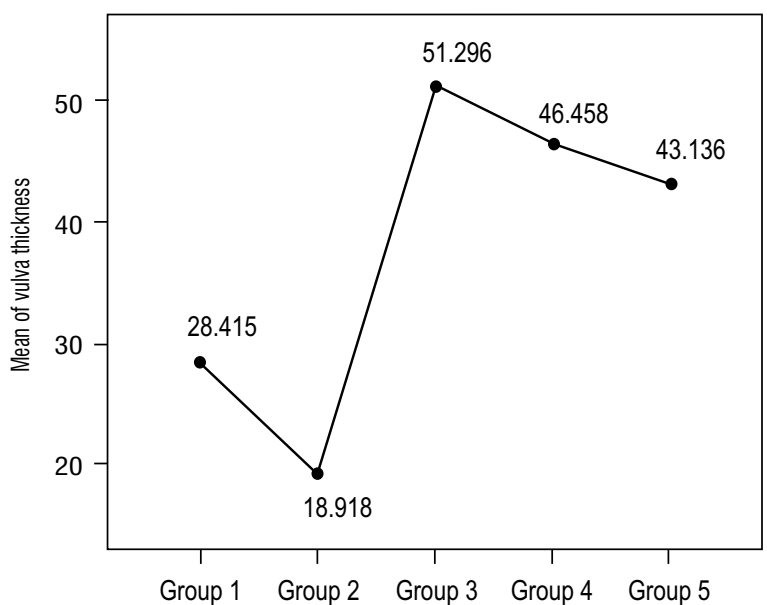

Figure 4. Differences in thickness of vulva.

which received treatment, presented various degrees of epithelial hyperplasia, and sometimes islands of hyperkeratosis (Fig. 5).

\section{DISCUSSIONS}

The experimental model of hormone replacement therapy, associated with surgically-induced anoestrus through bilateral ovariectomy in female rats, is wellknown [16, 28, 31].

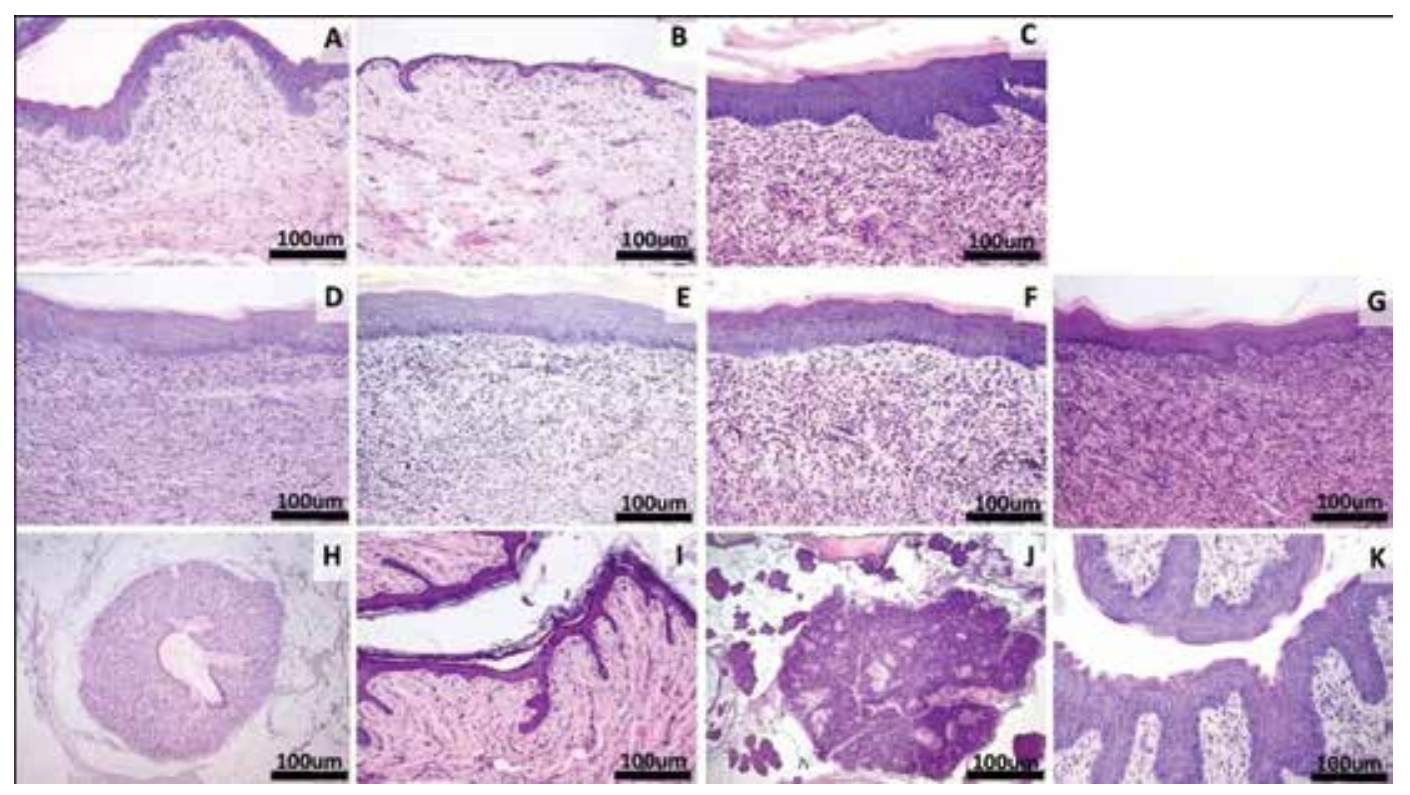

Figure 5. Effects of oestrogenic replacement therapy on vaginal (A, B, C, D, E, F, G) and valvular $(H, I, J, K)$ morphology. Control group (A) showing normal histology; ME group, vaginal epithelial atrophy (B); Oestrogen replacement therapy submitted animals exhibited marked epithelial hyperplasia, characterised by an increased number of cellular layers and thickness (C, D, E, F, G); Vulvar epithelial atrophy (I), normal female preputial gland histology $(\mathbf{H})$ - ME group; Marked vulvar epithelial hyperplasia $(\mathbf{K})$ and female preputial gland hyperplasia and hypersecretion (J), haematoxylin-eosin $\times 200$, scale bar $=100 \mu \mathrm{m}$. 
In accordance with the validated animal model, the histopathological analysis in group 2 found evident atrophy in the epithelium, chorion and glandular tissues of the vagina and vulva. This atrophy is associated with the absence of epithelial cornification, which are typical changes found in surgically-induced anoestrus in female rats. It is known that the cornification of the vaginal epithelium is a hormone-dependent phenomenon; some studies in literature report the presence of cornification in the absence of internal oestrogenic secretion in rats treated with oestrogens after birth $[13,15,30]$. In the groups treated with injectable oestrogens (Estradiol, Estradurin, Sintofolin), we found a marked presence of cell hyperplasia, along with a rich eosinophilic infiltration in the chorion and mast cell infiltration.

In this experimental study, Estradiol had the strongest effect on the proliferation of vaginal and vulvar epithelium, while Sintofolin had the weakest effect. Of the synthetic oestrogens, the Estradurin therapy yielded the strongest effect.

The response to injectable oestrogen treatment is fast and is due to the presence of a large number of oestrogenic receptors, either ER- $\alpha$, or ER- $\beta$, in the genital and mammary system $[19,27]$.

We found that all three types of oestrogens used treated vaginal and vulvar atrophy.

Our study proves that treatment with injectable oestrogens for 14 consecutive days triggers vaginal and vulvar hyperplasia, as well as the improvement of structural modifications exhibited in ovariectomised female rats, in keeping with the findings of Kangas et al. [14] or Basha et al. [4].

The application in medical practice of our results is an argument for using oestrogenic substances in hormone replacement therapy $[6,21]$.

The morphological modifications occurring during menopause, due to the typical oestrogen deficiency, benefit from a considerable number of treatments and therapies, which are, however, often controversial with regard to the benefits, risks and side effects [29, 32].

\section{CONCLUSIONS}

The vulvar and vaginal manifestations of the anoestrus phase are a direct response to the oestrogen deficiency. These changes are even more conspicuous when they occur suddenly, after a bilateral ovariectomy. Moreover, we have demonstrated that the Estradiol therapy induces the most evident histological modifications, compared to Estradurin or
Sintofolin. Estradiol was proven to be the most effective in treating the alterations occurring during surgically-induced anoestrus, while of the synthetic oestrogens, Estradurin had the strongest effect.

All three types of oestrogens, administered via injection over a period of 14 days, led to the involution of atrophy by inducing vaginal and vulvar hyperplasia, as well as the improvement in structural modifications appearing in female rats as a consequence of surgery-induced anoestrus.

\section{REFERENCES}

1. Acosta Jl, Mayer LP, Braden BB, Nonnenmacher S, Mennenga SE, Bimonte-Nelson HA (2010) The cognitive effects of conjugated equine estrogens depend on whether menopause etiology is transitional or surgical. Endocrinology, 151: 3795-3804.

2. Agacayak E, Basaranoglu S, Tunc SY, Icen MS, Findik FM, Kaplan I, Evliyaoglu O, Gul T (2015) Oxidant/antioxidant status, paraoxonase activity, and lipid profile in plasma of ovariectomizedrats under the influence of estrogen, estrogen combined with progesterone, and genistein. Drug Des Devel Ther, 9: 2975-2982. eCollection 2015. doi: $10.2147 / D D D T . S 82263$.

3. Barret-Connor E, Strynkel C (2001) Hormone replacement therapy (HRT): risks and benefits. Int J Epidemiol, 30: 423-426.

4. Basha ME, Chang S, Burrows $\sqcup$, Lassmann J, Wein AJ, Moreland RS, Chacko SJ (2013) Effect of estrogen on molecular and functional characteristics of the rodent vaginal muscularis. Sex Med, 10: 1219-1230.

5. Behr GA, Schnorr CE, Moreira JC (2012) Increased blood oxidative stress in experimental menopause rat model: the effects of vitamin A low-dose supplementation upon antioxidant status in bilateral ovariectomized rats. Fundam. Clin Pharmacol, 26: 235-249.

6. Benoit $T$, Leguevaque $P$, Roumiguié $M$, Beauval JB, Malavaud $B$, Soulié M, Rischmann P, Gourdy P, Arnal JF, Game X (2015) Use of local estrogenotherapy in urology and pelviperineology: a systematic review. Prog Urol, 25: 628-635.

7. Biglia N, Bounous VE, Sgro LG, D'Alonzo M, Gallo M (2015) Treatment of climacteric symptoms in survivors of gynaecological cancer. Maturitas, 82: 296-298.

8. Cen J, Zhang H, Liu Y, Deng M, Tang S, Liu W, Zhang Z (2015) Anti-aging effect of estrogen on telomerase activity in ovariectomised rats: animal model for menopause. Gynecol Endocrinol, 31: 582-585.

9. Cheng CL, de Groat WC (2014) Effects of agonists for estrogen receptor and on ovariectomy-induced lower urinary tract dysfunction in the rat. Am J Physiol Renal Physiol, 306: F181-F187.

10. DiBonaventura M, Moffatt M, Bushmakin AG, Kumar M, Bobula J (2015) The association between vulvovaginal atrophy symptoms and quality of life among postmenopausal women in the United States and Western Europe. J Womens Health (Larchmt), 24: 713-722.

11. Ghazanfarpour M, Sadeghi R, Roudsari RL (2005) The application of soy isoflavones for subjective symptoms and objective signs of vaginal atrophy in menopause: 
a systematic review of randomised controlled trials. J Obstet Gynaecol, 6: 1-12.

12. Han NR, Kim NR, Kim HM, Jeong HJ (2016) Cysteine prevents menopausal syndromes in ovariectomized rats. Reprod Sci, 23: 670-679.

13. Kang JS, Lee BJ, Ahn B, Kim DJ, Nam SY, Yun YW, Nam KT, Choi M, Kim HS, Jang DD, Lee YS, Yang KH (2003) Expression of estrogen receptor alpha and beta in the uterus and vagina of immature rats treated with 17-ethinyl estradiol. J Vet Med Sci, 12: 1293-1297.

14. Kangas $L$, Härkönen $P$, Väänänen $K$, Keskitalo J, Eigéliené $N$ (2014) Effects of ospemifene on breast tissue morphology and proliferation: a comparative study versus other selective estrogen receptor modulators in ovariectomizedrats. Horm Metab Res, 46: 328-332.

15. Katsu Y, Takasu E, Iguchi T (2002) Estrogen-independent expression of neuropsin, a serine protease in the vagina of mice exposed neonatally to diethylstilbestrol. Mol Cell Endocrinol, 195: 99-107.

16. Lamas AZ, Caliman IF, Dalpiaz PL, de Melo AF Jr, Abreu GR, Lemos EM, Gouvea SA, Bissoli NS (2013) Comparative effects of estrogen, raloxifene and tamoxifen on endothelial dysfunction, inflammatory markers and oxidative stress in ovariectomizedrats. J Steroid Biochem Mol Biol, 138: 107-115.

17. López-Belmonte J, Nietro C, Estevez J, Delgado JL, Moscoso del Prado J (2012) Comparative uterin effects on ovariectomized rats after repeated treatment with different vaginal estrogen formulations. Maturitas, 72: 353-358.

18. Lucan L, Lucan VC, Tabaran FA, Stamatian F (2013) Changes in the urinary bladder morphology, mast cell population and estrogen receptor alpha expression following ovarectomy and chronic estrogen replacement therapy in albino rats. Acta Endocrinologica (Buc), 9: 11-22.

19. Montoya TI, Maldonado PA, Acevedo JF, Word RA (2015) Effect of vaginal or systemic estrogen on dynamics of collagen assembly in the rat vaginal wall. Biol Reprod, 92: 43.

20. Mørch LS, Kjaer SK, Keiding N, Løkkegaard E, Lidegaard Ø (2016) The influence of hormone therapies on type I and II endometrial cancer: a nationwide cohort study. Int J Cancer, 138: 1506-1515.

21. Nappi RE, Palacios S (2014) Impact of vulvovaginal atrophy on sexual health and quality of life at postmenopause. Climacteric, 17: 3-9.

22. Nevalainen $T$, Berge $E$, Gallix $P$, Jilge $B$, Melloni $E$, Thomann $P$, Waynforth B, van Zutphen LF (1999) FELASA guidelines for education of specialists in laboratory animal science (Category D). Report of the Federation of Laboratory
Animal Science Associations Working Group on Education of Specialists (Category D) accepted by the FELASA Board of Management. Lab Anim, 33: 1-15.

23. Palacios S, Mejía A, Neyro JL (2015) Treatment of the genitourinary syndrome of menopause. Climacteri, 18: 23-29.

24. Palma F, Volpe A, Villa P, Cagnacci A (2016) Vaginal atrophy of women in postmenopause. Results from a multicentric observational study: the AGATA study. Maturitas, 83: 40-44.

25. Predná L, Habánová M, Sláviková E, Wyka J (2015) Hormonal contraceptives and hormone replacement therapy as a possible factor of breast cancer. Rocz Panstw Zakl Hig, 66: 269-274.

26. Robinson D, Toozs-Hobson P, Cardozo L (2013) The effect of hormones on the lower urinary tract. Menopause Int, 19: 155-162.

27. Skala CE, Petry IB, Albrich SB, Puhl A, Naumann G, Koelbl H (2010) The effect of hormonal status on the expression of estrogen and progesterone receptor in vaginal wall and periurethral tissue in urogynecological patients. Eur J Obstet Gynecol Reprod Biol, 153: 99-103.

28. Ström JO, Theodorsson A, Ingberg E, Isaksson IM, Theodorsson A (2013) Ovariectomy and 17betaestradiol replacement in rats and mice: a visual demonstration. Life Sci, 138: 107-115.

29. Sturdee DW, Panay N (2014) Recommendations for the management of postmenopausalvaginalatrophy. International Menopause Society Writing Group. Horm Metab Res, 46: 328-332.

30. Takasugi N (1976) Cytological basis for permanent vaginal changes in mice treated neonatally with steroid hormones. Int Rev Cytology, 44: 193-224.

31. Unkila M, Kari S, Yatkin E, Lammintausta R (2013) Vaginal effects of ospemifene in the ovariectomized rat preclinical model of menopause. J Steroid Biochem Mol Biol, 138: 107-115.

32. Wuttke W, Jarry H, Haunschild J, Stecher G, Schuh M, Seidlova-Wuttke DJ (2014) The non-estrogenic alternative for the treatment of climacteric complaints: Black cohosh (Cimicifuga or Actaea racemosa). Steroid Biochem Mol Biol, 139: 302-310.

33. Yang X, Li YZ, Mao Z, Gu P, Shang M (2014) Effects of estrogen and tibolone on bladder histology and estrogen receptors in rats. Chin Med J (Engl), 18: 1895-1907. 